Иван Котев

\title{
НЕКОИ КАРАКТЕРНИ И ФИЗИЧКИ ОСОБИНИ ОДРАЗЕНИ ВО МАКЕДОНСКИТЕ НАРОДНИ ПОГОВОРКИ И ПОСЛОВИЦИ
}

Апстракт: Во прилогов станува збор за пословиците и поговорките како фолклорен жанр во кој се отсликуваат карактерните и другите особини што се својствени на луѓето. Овие кратки литературни народни творби го отсликуваат животот на човекот од далечното минато до денеска. Во нив се прикажани и добрите и лошите особини на луѓето.

Пословицата и поговорката кажуваат и укажуваат, исмејуваат и советуваат, нудат вдахновение и смирување. Нашиот, македонскиот анонимен творец дал свој суд за речиси сите сфери од животот, навлегувајќи дури и во сферата на: интимата, психологијата и философијата, се разбира на свој здрав и разбирлив начин.

Негативните особини - алкохолизам, коцкање, крадење, кудење, завист и сл., исто се предмет на опсервација. Поговорките и пословиците навлегуваат длабоко во суштината на нештата. Тие се директни и речити.

Клучни зборови: пословица, поговорка, карактерни особини, луѓе, живот.

Пословиците и поговорките се трајни цивилизациски вредности вткаени во литературата на еден народ. Македонскиот народ во својот милениумски творечки о̀д создал бројни и трајни духовни творби со кои се гордеат многу генерации. Во нив е вткаен животот на македонскиот човек од најдалечното минато до денес. Македонскиот фолклор истовремено е историја и песна, минато и сегашност, надеж и иднина. Од фолклорот се инспирирале и од неговите извори жедно црпеле безброј творци во сите области на уметноста. Особено фолклорното влијание дошло до израз во книжевното творештво, а пошироко тоа се вплотило во севкупното духовно наследство на човештвото. Народните пословици и поговорки спаѓаат меѓу најомилените и најчесто творечки манифестирани фолклорни творби. Често тие се „запршката“ или зачинот на повеќето приказни, песни, обични кажувања или искажувања. Произнесени во убава и збиена форма и искажани на чист народен јазик, тие го пренесуваат мислењето и вековното искуство на народот за различните збиднувања од секојдневниот живот. Живо, а најчесто остро и многу духовито ги карактеризираат лошите и добрите особини на поединците, групите или на целите народи, при што го жигосуваат злото, борејќи се против насилството и расипништвото. Народната пословица ја прославува слободата, се радува на добрите дела и ги упатува луѓето да ги создаваат; ја величи чесната работа и трудот воопшто, а ги жигосува, исмејува и ги осудува нечесните постапки, злоупотребите, недостатоците на поединците, на одделни групи и општеството во целина - со еден збор, го искажуваат народнот 
гледиште врз севкупниот живот на поединците и на народот (Котев, 2012, 7 8).

Пословицата се дефинира како „..синтетизиран мисловен израз (најчесто: двочлен), кој содржи суд за некого или нешто... Поговорката, пак, по својата уметничка форма е едночлен афористичен израз, кој обично претставува споредба“" (Саздов, 1970, 112-113). Поконцизна дефиниција ни дава познатиот современ проучувач на македонскиот фолклор д-р Марко Китески, кој, пословиците ги дефинира како „... двочлени изрази, иако можат да бидат искажани и со повеќе членови, па дури и во стихови, додека поговорките се пократки во вид на кратка изрека или израз“ (Китевски, 2011, 14).

Пословиците се избрусан дијамант, бесценет камен, кој никогаш не ја губи својата вредност и убавина. Пословиците се, како што вели една арапска пословица, зрак што го осветлува мракот. Навистина, често една пословица повеќе и појасно зборува и осветлува некое прашање или објаснува некој проблем, отколку долги говори или повеќе напишани страници. Затоа народот толку многу ја сака пословицата и толку многу ја употребува.

Во овој скромен прилог ќе се осврнеме на некои карактерни и физички особини што нашле одраз во овие кратки, но толку убави жанрови со силен книжевен набој.

Алкохолизмот, како негативна појава, која настанува со долготрајно и прекумерно пиење и доведува до здравствени, семејни и пошироки општествени проблеми, силно е жигосан: Кој го препива виното, р'стура си куќата. Алкохоличарот е опасен за околината: Лудјо од пијанјо бега̀л. Пословицата укажува и жигосува истовремено: Дек’ пии, там спии. Укажува на последиците за здравјето и секојдневните навики и потреби и нивното нарушување: Кој вичера р'кѝа, дуручкува вода; осврнувајќи се на крајно лошото влијание на алкохолизмот, народниот творец резигнирано ќе заклучи: P'кѝа и гробишта не ми фали. Народниот мудрец, укажувајќи на последиците од зависноста, констатира: Кочүка́ро се коцฺка дудѐка може да гледа; крада́чо ке краде додѐка може да трче; пијаницата ќе пии ду смртта. Пиењето повлекува последици: Ракиата на никој не простува. Алкохолот ги погодува сите социјални групи и поединци: Р'ки'ата не пита цуар ли си, гуведа́р ли си. Судбината на алкохоличарот е зацртана: Чашка по чашка - роб; шише по шише - гроб. Поговорките и пословиците укажуваат и на последиците по психичкото здравје на човекот: Р'ки'ma ќе ти испии ак'ло. Алкохоличарот не ужива углед, неговиот статус е многу низок и никој не го почитува: Шише носеш ле у иебо, ут тебе аир нема. Во таа смисла: Пијаницата а пулвйн чувек. Ги има стотици во тој поглед и не е можно да се искоментираат сите околности за кои се создадени поодделни пословици или поговорки. Но, ќе цитирам една современа пословица во стихови што се темели на исказот: Пијан - чекор, создадена за одредена личност, која е позната во едно село од 
Струмичко: Брзај, брзај, прваче, / во школскит двор, / те чека учителот Ване / пијан - чеко̀р. (Исмевање на учителот кој пиеше.) $)^{1}$

Инаку, „зборот алкохол потекнува од арапската сложенка al-kohlu, што значи многу фин. Означува најдобар, совршено пречистен прав, на пример од кората на кино-дрвото, железо и др.“ (Вујаклија, 1954, 30). Камо да е така! Ама, овој збор настанал многу векови пред да отпочне индустриското производство на алкохолот.

Безобразието и безобsирноста, како негативни и општествено штетни појави, исто така се подложни на острата критика и укажувањата на пословиците и поговорките. За ликот на луѓето со такви особини особено речита е изреката: Главата а покрѝва, газо си открѝва. На туѓа сметка или на сметка на својата фамилија, тие трошат безоблирно, па народниот творец резигнирано заклучува: Д’ беше извор, ќе пресушеше. Безобразието најчесто е поврзано со лагата и измамата, затоа се вели: Ем не пљачкат, ем не лажат, или: Ем те пьачка, ем очи ти мачка. Во таа смисла: Жит'то ти зима, сламата ти дава. Безобразието нема граници. Се пренесува и се рефлектира и на економски план: Лебо ти јаде и гробо ти копа. Уште појасно: Ha паapme брат ти се праве. Безобразниот е и безоблирен „паразит“: Н’ ка̀то ти седам, н’ браата ти се серам. Следува еден мудар исказ, колку да се знае дека е обележен и забележен. Таквата личност нема ни срам, ни образ. Безобразниот $C^{\prime}$ с л'жищата срка, с'с дриката у очите ти брка. Варијанта: C'с л'жицата крка, c'c рачката у учите ти брка. Таквите немаат почит дури ни спрема кумот: Стани куме да ми седнат децата. Таквите се Уд вјаарта н' вонка.

Благодарноста и човечноста се позитивни особини што ја красат личноста. Благодарноста, всушност, е атрибут на човечноста. Да знаеме и да умееме да се заблагодариме на оној што ни помогнал и ни сторил нешто добро е израз на човечност, а човечноста е моралното однесување на луѓето во согласност со етичките норми и вредностите што се почитуваат во една заедница. Една од одликите на човечноста е скромноста: Кој е благода́рен, благода́рен е и од една игла. Човечноста подразбира добар однос и кон животните и кон останатиот жив свет: На мрафка не н'згазува. Дури и животните знаат да бидат благодарни: Кучето дека јаде леб, таму бране. Често во пословиците, со оваа тематика, ќе се соочиме со бројни совети: $\mathrm{Ha}$ болнио проговори му, на страднио подај му рака. Треба да сме внимателни со оние што ни дариле или ни даруваат нешто вредно: Не ја пљуј раката шо те ране. Или: Рака шо дава, не се сече. Луѓето, сакале или не сакале, се упатени еден на друг. Често може да се слушне: Терам(е) рамо за плачене, или поговорката: Подадена рака, блажена рака.

Клеветењето, како негативна особина, е исто под опсервација на народниот творец. Тој укажува на штетноста на оваа човечка особина не само за наклеветениот (често пати и невин човек), туку и за општеството во целина. Со клевети се уништувани човечки животи и се растурани цели семејства, се

\footnotetext{
1 Сите цитирани поговорки и пословици се од Иван Котев. 2012. Мудроста на вековите. Македонски народни пословици и поговорки од Струмица и Струмичко. Струмица: ЛУ Библиотека „Благој Јанков Мучето“, 30-32.
} 
разорени и домови. Се клеветело од разни побуди: материјална добивка, одмазда, од жед за доминација во одредена средина и од други лични побуди. Клеветниците се омразени во средината од која произлегуваат и, кога ќе се разоткријат, средината ги отфрла, но последиците остануваат. Таа како Дамоклов меч виси над главите на обичниот човек: Ако сакат да го отѐnam кучето, ќе кажат оти е бесно. Јавното мислење е подложно на манипулации: Да не се каже оти сестра ти е курва, а ти после оди и докажувај оти немаш сестра. Сепак, стои констатацијата: Кој клевѐте, нема да процвѐте.

Клетвата означува проколнување на одредена личност со цел да го најде зло, несреќа. „...повеќе колнат жените - позната е мајчината клетва, но за тешка се смета и татковата и кумовата клетва; се смета дека клетвата достига до деветтото колено, а ако не го стигне тој кому му е упатена, може да го стигне неговиот наследник; народот многу се плашел од клетва, па избегнувал да прави лоши дела...“ (Макаријоска, 2016, 209). Во клетвите луѓето истураат горчило и бес, колнат со пена на устата, често дури и плачејќи: Аир да не видеш! Има мајки што го колнат дури и сопствениот син ако манифестира неблагодарност и ги тероризира родителите: Apáм d’ $m u$ u млекото шо с'м те дуйла! Клетвите се упатени кон насилниците, убијците и кон сите оние што на еден или на друг начин ги повредуваат луѓето: Бел ден да не виде, да даде Господ, или: Беста да го фате. Метафората е честа во овој вид фолклорни творби: Д’ ти апнам ут чиницата. Слична на оваа е: Да го видам под бело платно, или: Д’ ти даде Госпот кељь и краста и орлови нокти! Ако некој украл нешто, следува клетвата: Да му исаанат рациите. Во свеста на народот живеат ужасите што ги доживеале од бројните странски завојувачи, кои краделе, убивале, пљачкале и палеле: Да те газат Tamápe и Алама́не. Нашиот човек, иако колне, сепак е свесен дека клетви гробишта не праат. Затоа, се ориентира кон поведри теми: K'ни го чувѐк кашта да праве и пари да нема. Има уште поинтересна: K'ни го чувѐк у една гудиेна н' три керкки свадби da нanpáa.

Вистината и лагата длабоко се вгнездени во свеста на нашиот човек. Тој ја возвишува вистината, а ја осудува лагата како крајно штетна и опасна карактерна појава, укажувајќи: Ако изла́жеш една́ч, вторпат не ти веру́ват, споменувајќи ги лековерните на еден многу убав начин: Ако ме изла́жеш еднч - ара́м да ти и; ако ме изла́жеш двапати - ала́л да ти и. Има луѓе што се познати по таа своја особина. Лажењето за нив е нешто сосема нормално, дури и го практикуваат. Во таа смисла, народниот мудрец со една поговорка, лапидарно ги отсликува ваквите личности: $A$ зејна́, а изл’жа́. Лагата, како порок не е од денеска. Таа постоела отсекогаш, па народот сковал убав бисер: Ако умрѐ л’жа́чо, лаајште не умрјаа (...лагите не умреа). Овој исказ се поврзува дури со конкретна личност: Ако умрѐ Настрадин-Оца, лажите не сврий'a. За среќа, лагата е кусовечна: Лажа и тајна не се кри'ат вечно. За жал, понекогаш лажачите успеваат: Со лагата во устата седело си направѝ (Со лага се омажила, се скуќила, си направила дом). Стои и констатацијата: Тај шо лаже, сам се лаже, оти Една лажа раѓ многу лажи. За жал, има луѓе што дури веруваат во своите лаги, па пословицата констатира: Едно е да лажеш, друго е да живееш во лажа. Но: Лаажта има кус век. Па, 
констатацијата: Лаажта дека руча, не вечера. И на крајот како опомена: Кога лажеш и Господ го лажеш. Но, наспроти лагата секогаш стои вистината, како бедем и со конкретни показатели: Б'кл'вата ако а изедена, типщйата стоа. Или: Ако коза лаже, рог не лаже. И, како заклучок: Лажи ного, истин'та а една́ (...вистината е една).

Вистината е позитивна карактерна особина. Луѓето што ја зборуваат вистината се опуштени, без грижа на совеста, иако во практиката често страдаат поради својата вистинољубовост. Со доза на философска нота, народниот мудрец ке каже: Вистината е длабока вода, со што ѝ се придава голема важност на вистината и на вистинољубивоста и се споредува со животворното значење на водата. Дури постои изрека со сосема јасна компарација: Водата и вистината се исти. Но, и: Вистината најмногу боли. Во таа смисла и пословицата: Вистината што боли е подобра од лагата што помага, или: Поарно горчлива истина уф очи, отколку слатка лажа зад грп. Таа, вистината, е вечна: Вистината се тенче, ама не се кине. Вистината е над лагата и сомневањето, оти Истин'та никој не мож' да а промѐне, оти Истин'та а една́. И, да се знае: Пословицата е проверена вистина. ${ }^{2}$

Властољубивоста и аривизмот, како карактерни особини, исто така се предмет на опсервација. Практикувањето на власта и односот кон граѓаните нашла одраз во пословиците и поговорките. Овде се навлегува во психологијата на човекот, во неговите интелектуални можности и карактерот: Ако сакаш да му видеш ак'ло на чувек, дај му влас!, но, А дојде на чело, не мисле на село - и констатацијата: Власта го расипува чувѐко. Во таа смисла една многу индикативна пословица: Во селото на слепите кој е со едно око, стану́ва кмет. На оваа тематика се раѓаат и нови пословици и поговорки: Едната (влада) плајќа и инвента́р врајќа; другата - ни плајќа, ни инвента́р врајќк.

Во пословиците и во поговорките што се предмет на ова излагање е опфатен животот во речиси сите негови манифестации, па следствено, не е можно да се осврнеме на секоја тема посебно. За тоа би требало да се напише посебна монографија. Затоа, сосема бегло ке се осврнеме уште на неколку тематски подрачја.

Вообразеноста, како негативна карактерна особина, исто така, се наоѓa под будното око на народниот опсерватор. Тој силно ги жигосува луѓето, кои отстапуваат од кодексот на однесување, укажувајќи директно: Аnна́л праз, н’дуја́л газ. Се однесува на луѓе, кои до вчера никој не ги забележувал, а сега, по некоја случајност, се здобиле со извесни привилегии и наеднаш никого не познаваат, не признаваат, со еден збор се прават важни. Па, во таа смисла и поговорката: Бог да чува, ќораво да не преглѐне. Таквата личност дуа се к'mу питѐл н' бунйште. За вообразените има еден заеднички именител, искажан во поговорката: Ѓорам табенѝ, ча́нта писќилѝ (во смисла: се прави важен, а за никаде е!). Луѓето што си вообразуваат дека се над другите, дури јасно се диференцираат и во економски поглед и сакаат повисок статус: $K^{\prime} \partial u ф \grave{e} u$

\footnotetext{
${ }^{2}$ Само една кратка констатација: во мојот полувековен собирачки стаж сретнав и
} запишав многу повеќе пословици и поговорки за лагата, отколку за вистината. 
б’cмá не оде, к’дифѐ и свила - оде. (Богат со богат оди, а не оди богат со сиромав).

Осврнувајќ́ се на ваквите сфаќања и искази, народот предупредува: Koj лета висо̀ко, ниско паѓ. Или: Кој пљуа уф небото, пљунката ќе му падне на лицето. Следува совет: Не пљуј висо̀ко, оти пљунката ќе ти се в’рне на лицето. Таквите личности се одбивни, не се сакани од околината: Него у сеелто го нејќ́ат, он пита за поповата ќерка. Таков човек кога ќе се дојде до каква било власт, веднаш се експонира и - се легитимира. На повидок излегуваат неговите нарцисоидни и други негативни особини, па следува оценката: Ќ дубѝи функција, ќе почне лива́нто да моче, поради тоа што: Удрѝ му славата у главата.

Давањето и земањето (во смисла: позајмување за услуга) исто така зазема забележителен простор во македонските кратки жанрови. Во своето секојдневие нашите луѓ биле упатени еден на друг. Тие се услужувале, си позајмувале, си помагале и тоа се рефлектирало во пословиците. Евидентна е дидактичката функција на пословиците. Еве еден речит пример: Ако сакаш да зимаш, научи се да даваш, оти: Д'ваајнто не е ут сој. Или: Даваајнто е тешко, ама тераајнто е потешко. Не е лесно да побараш нешто, а не си сигурен дека ќе добиеш.

Дволичноста, добрината, лошотијата и злобата, домашното огниште, достоинството и другарството, исто така се широко застапени. Дволичноста е негативна карактерна особина. Дволичниот човек е непостојан, нему не можеме да му веруваме, оти тој: Врте се к'то с'нчоглет или пак: Врте се н' дек' дуа вет'ро. Таквиот: Едно̀ мисле, друго кажу́ва, трето работе. Дволичниот човек: Преде на две вретена (Ики фукерлии) и од него подалеку! Тие се крајно деструктивни. Се раководат според геслото: $H a$ кучето: „Држ!“”, на зајако: „Беги!“ За да го задоволат своето его и да се експонираат, тие: Пред луѓето фрлат нед, а пред своите - ж'чки и оцет. Таквите луѓе служат за презир: Мислех дека а чувѐк, а он бил м’а́ре. Народниот творец не би бил тоа што е ако добронамерно не подели и некој совет, со надеж дека таквите ќе се освестат: Н’ два стола не се седе. И слична на претходната: $H^{\prime}$ две ора не се игра. И, како заклучок: Чувѐко а пулвйна анѓел, пулвйна ѓавол.

Овие пословици се вистински кодекс и патоказ како да се однесуваме и како да ги негуваме и чуваме достоинството и другарството, а да се бориме против дволичноста и злобата: Ако не моаш да му направеш арно, б'ре не му прави лошо н' чувѐк, или: Не се надевај на арно, ако прааш лошо. Добриот човек: Дава си кушуљата уд грбо. Се верува: Добар човѐк н'ф 'ка́ носе. Дури и: Душ' 'ma c' ја дава. Добрината секојпат не се почитува и на доброто не се враќа со добро: Прави добро, чекај лошо. На луѓето не може да се угоди: И мост да бидеш, па не чинеш. Но, сепак: Тај шо праа арно, чека го арно. Во тоа е високата морална, интелектуална и дидактичка вредност на нашата народна пословица - доброто секогаш е посилно од лошото, од злото: Напри добро $u$ фрли го у моорто, оно ќе исплива.

Достоинството е доблесна и почитувана морална карактерна особина. Достоинствените луѓе се почитувани од средината во која работат и живеат. 
Таквите личности се раководат од девизата: Поарно да умреш поштено, отколку да живееш срамно. Достоинствениот човек е горд и самоуверен. Тој не отстапува од своите начела: Понапрѐ ќе висам на гранка од брест, отколку да бидам брест. Тие не даваат да падне петно на нивното име: Подобро окото да ти излѐзе, отко̀лку име да ти излѐзе. Во кратките жанрови со оваа тематика се потенцира достоинството наспроти сервилноста, гордоста наспроти потчинетоста, па ќе ја сретнеме и пословицата: Ако на секој ја сваљу́ваш капата, скоро ќа а здереш (... ке ја содереш). Затоа, Поарно да те мразат, отко̀лу да те жаљат. Човекот со достоинство и интегритет се залага за чесен живот: Поарно сиромаштѝ' $а$, отко̀лку срамотй'a.

Завидливоста, исто така, е забележителна карактерна црта. Народните кратки жанрови силно ги жигосуваат луѓето, кои ја имаат таа особина, па генерално укажува: Koj завйде, ич да не виде. Се укажува на штетното влијание на завидливоста: Завидливоста е прф кумшйа на кавгата. Завидливиот човек губи од својата човечност, бега од реалноста и се претвора во морално чудовиште. Завидува на соседите, пријателите, па дури и на сопствените браќа и сестри. Таквиот мисли дека на комшијата: И петлите му несат јајиа, завидува на многу победните од него. Тој: Има сто офичи, а з 'видува на тај што има една. За него: Н' кумши'ата и питѐло несѐл јајца.

Завидливоста и злобата понекогаш се испреплетуваат, се надополнуваат: Он е кайь у неговата нива да врне, а у мој'та - не. Таквиот: Само у чуждата чинй'а гледа. Злобата ја труе душата на човекот. Злобниот човек и не може да се нарече човек во вистинска смисла на зборот. Тој е опасен за својата околина и пошироко. Тој: Д’ може уф една капка вода ке те удаáве. Злобниот, во буквална смисла на зборот е - бездушник, оти: Злобата ja јаде душата, како p'ѓата железото. Таквите луѓе стануваат сѐ полоши: Дујде време да не викаме: н' кумши'ата д'му умре коазта, туку: кумши'ата d’ умре, коазта д' мо а зем'ме (... козата да му ја земеме).

Инаетот е негативна карактерна особина. Луѓето со таа особина држат до своето мислење или став иако не се во право. Таквите: Уд газо ке си апнат, yд инаámo не си nаѓam. Таквите имаат и една друга негативна особина: тврдоглавост. Тие не примаат никакви совети: Ем ак'л нема, ем совети не прима, иако најчесто го извлекуваат подебелиот крај: Воло рии, ама прста на грбо му паѓa. За таквите важи поговорката: Ем шуто, ем боде или: Ем иутливо, ем бодливо. Таквите луѓе: За инат една врејќа сол ќе изедат. Не си ги признаваат грешките и недостатоците: Мачка на грбо не паѓa. Се смета дека оваа крајно негативна особина тешко се исправува, дека е наследна: Див миндел и да го калѐмеш, па диво пушта. Не можејќи да дејствува со совети, па и со други порадикални мерки со кои би се отстранила оваа особина, народниот мудрец заклучува: $H^{\prime}$ инато лек нема. Таквиот човек: H’ инато си умира, затоа: Од инатлѝв и мрзлѝв - бегај! Тие дејствуваат крајно деструктивно и не се менуваат. Во таа смисла е поетската поговорка: $\mathrm{Ha}$ кривото дрво и жарта мо а крива.

Искреноста е една од најубавите и најпочитуваните човечки особини. Искрениот човек е вистинољубив, не ги искривува фактите, не лаже и секогаш е отворен за разговор. Тој е подготвен да спори за своите погледи и постапки, 
но со докази: Ак' с’м го издѐл зелнико, типций 'ата а н'мегда́но (...mепсијата е на мегдан, т.е. пред нас). Често пати искрениот човек страда токму поради таа благородна особина: Искрениот човек секогаш е во неволја. И покрај тоа, искрените луѓе порачуваат: Криво да седеме, право да говореме. За човек со вакви сфаќања важи правилото: Шо а пред него, $m$ 'ва а з’д него. Со вистината се олеснува душата: Шо н' душ'ma, m'ва н' $y c m$ 'mma. Таквиот човек тоа што го има во себе, го кажува јавно: Шо н'ум, т'ва н' друм.

Итрината и снаодливоста, како рефлексии на интелигенцијата, се застапени во бројни кратки жанрови. Народниот творец со почит се однесува кон луѓето со овие особини: Акма́к лозе копа, јуна́к вино пие. Снаодливиот човек е ербап, на таквиот „очите му играат четири“ и секогаш ќе најде решение за секаков проблем. Не останува ниту гладен, ниту жеден: Биди epбán, jaдu ќeбán. Таквите луѓе се подвижни, статичноста им е туѓа и секогаш можат да ја избегнат неволјата: Беганова мајка не плаче, Стојанова плаче. Или: Бежан рипа, Стојан рика. Итриот им порачува на своите пријатели, кои сакаат да му напакостат на итрецот, па ке им каже: Виа дека шиите, јас се спровйрам, или: Виа дека оате, јас се враќам. Таквиот: Гледа с'с читйри очи, дури, и: Да го врзеш, ќе се одврзе. За снаодливите луѓе важи исказот: Да знааш не е марифѐт; марифет е да умѐеш. А умеењето се манифестира во тоа, ако си способен: Да продааш сама́ро, да купеш мага́ре. Секојпат и секаде е подготвен да дејствува: Дек’ оде Демја́н, с’с него си носе темја́н. Итриот човек: Едно̀ ќе даде, три ќе земе.

Некои од овие кратки жанрови настанале во поново време, дури се знае и случајот врз кој се создадени. Има еден израз од понов датум: Ду во 'ата а $p^{\prime}$ бо̀m 'ma. ${ }^{3}$ Ова е уште еден показ и доказ дека поговорките и пословиците се

${ }^{3}$ Се раскажува анегдотата за овој исказ, дури се посочуваат и личностите. Еве ја суштината: познато е дека варџиите од с. Костурино, Струмичко, прават многу квалитетна вар и ја продаваат во блиските градови и села. Се случувало, иако ретко, некоја вар да не е со потребниот квалитет. Имено, при гаснењето имало повеќе камен отколку вар, па доаѓало до расправии. Еден варџија продал поголема количина вар на еден човек, кој ја платил како да е прва класа. Арно ама, испаднало дека варта не е со потребниот квалитет и човекот, гледајќи ги купиштата бели камења, многу се налутил и порачал варџијата поубаво да не доаѓ во неговиот град, оти ќе зажали. Варџијата сериозно ја сфатил пораката и една година навистина не одел таму. Арно ама, од нешто требало да се живее. Со пресметлив ризик да биде и натепан, го вклучил камиончето и тргнал. Кога го видел, оштетениот му пришол и нервозно прашал што бара тука. Варџијата рекол дека сѐ може да се среди со разбирање и дека е готов на разумно решение и, ако треба, ќе ја надополни штетата. Затоа го прашал оштетениот:

- Каде ја гасеше варта?

- Дома. Има поток што минува зад куќата, па не е проблем за вода.

Варџијата зел една поголема кофа, ставил неколку парчиња од варта и се симнал до блиската река. Ставил вода и варта почнала да се топи. Како масло! Во кофата не останало ниту едно каменче. Погледнал кон човекот и му рекол:

- До водата ќe е работата! Гледаш ли каква е мојата вар? Подготвен сум да ти дадам половина од варта што ми ја плати и да си останеме пријатели.

Така и сториле. 
создавале и се создаваат и денеска и се неисцрпен извор на мудрости и поуки. Итрите луѓе се многу внимателни затоа што знаат дека: И итра лисииа паѓa во cmanuщ̧a. Кога можат, ги организираат работите да им ги вршат други, раководејќи се од девизата: Коа има маша, не си горам ращете. Итриот: Не можеш да го фанеш ни за главата, ни за пашката. Снаодливиот: Траа и праа.

И комарот, како крајно негативна појава, кај луѓето што ја поседуваат таа карактерна особина, е санкциониран: C'с печалено от комар куќа не се граде. Се укажува на тоа дека од такви пари нема фајде, дека пак ке одат таму, од каде што дошле: Комаро а брашно на зајм. Со цел да ја спречи или барем да ја ублажи оваа негативна појава, народниот творец укажува дека и покрај ретките добивки: Комарциата нико'ш не е у ќар, и се доаѓа до одредено сознание: Ракиата а ду време, а комаро до жив живот.

Корупцијата и митото, поими што укажуваат на морална расипаност, изопаченост, разврат, поткуп, подмитување, тие вечни рани на општеството, и не само нашето, исто така нашле одраз во пословиците и поговорките. Народниот творец предупредува со еден лапидарен стил, својствен само за нив: Дафчо дава ле, не е на арно (мито, поткуп со пари или други добра). Луѓето со текот на вековите едноставно мислат дека само ако дадеш, поткупиш, можеш да се надеваш дека работата ќе биде завршена, откако се исцрпеле регуларните постапки, па резигнирано ќе каже: Дафчо ќе сврше работа. Или: Дафчо нека а жив. И, слична на оваа: Дафчо штом р’боте, ќе биде. Корупцијата навлегува во сите пори на општеството, па дури станува нешто нормално, вообичаено: Кај доктор не се флева со празни раце. За луѓето, особено државните службеници, кои се подложни на корупција, има пословица: Леб јаде, на катра́н мириса. Кај ваквите важи пословицата: Печено на маса, зако̀но под маса. Има луѓе подложни на корупција, ама не се задоволуваат со малку, па оттука и поговорката: Спрема агата и бакшѝшо. Народот дури има и разбирање за корумпираноста ако е во помала мера. До одредена граница има и толеранција: Тај што си брка раците у медо, ближе cu прст'те. Но, има и предупредување: тие се опасни луѓе! Затоа: Ф'рли му коска, оти ќе те изѐде.

Крадењето во нашите простори како да се стопило со вечноста. Оваа крајно негативна карактерна особина ги боде очите на обичниот, чесниот човек. Народот ги знае арамиите, тие се меѓу нас, па резигнирано ќе каже: Арамй'a c'c m'nù'a. Вешти, крадачите ретко се фатени на местото на крадењето, па народот ќе рече: Апашо може да го фане само апа̀m. Во осудата на овој „плевел“ се повикува дури и Господ: Ако крадеш, Господ ќe mе казне. Иако го осудува крадењето, народот понекогаш има разбирање и за оваа крајно негативна појава. Многу луѓе останаа без работа, немаат егзистенција, па, оценувајќи ја ваквата појава, народната поговорка констатира: Краде за да јаде, но и констатацијата: Арамил'ко врх има, корен нема. Крадците се опасни, ја поседуваат особината на мимикрија: знаат да се стопат со средината во која живеат и затоа понекогаш тешко се откриваат, па народниот мудрец ќе каже: Дејне светѝ'a, ноќе арамй'a. Таквите луѓе се: Уд вјаарта н’ вонка. Сакајќи да укаже на нив како на бесчувствителни луѓе, 
народниот гениј констатира: Крада́чо душа нема. Па, во таа смисла: Крада́чо $u$ лажа́чо немат ни пето̀к, ни свето̀к.

Лакомоста и ненаситноста исто нашле свој одраз во македонските кратки жанрови. Таа особина се исмејува и се жигосува безмилосно. Лакомите луѓе, на еден начин, се презрени и за нив дури се кажуваат и анегдоти. Така, исказот: Уд дек са тиа греди? има своја предисторија преточена во анегдота:

Некој лаком човек отишол кај пријателот на гости. Седнале да ручаат. Арно ама, јанијата била многу жешка, штотуку симната од огинот. Лакомиот гост немал трпение и почнал да јаде. Уште со првата лажица толку многу се изгорел, што од очите му потекле солзи.

За да не го забележат, погледнал во таванот. Не знаел што да каже, па прашал:

- Уд дек’ са тиа греди?

- Од Лаком Дол! - одговориле синовите на домаќинот.

Луѓето со ваква карактерна особина губат чувство за срам од луѓето и страв од Господ: На лакомјо му е сеедно дали е гозба или помен. Луѓето ги гледаат со презир: Чинеш, ни апна́л, ни сркна́л. На нив сѐ им е малку, сакаат повеќе, па оттука пословицата: Човечкото око насидба нема. Лакомоста и ненаситноста одат рака под рака. Лакомиот не се задоволува со малку, нема „насидба“. Тоа убаво го илустрира пословицата: Ти му даваш прст, он ти сака цела рака. Или: Видѐ уши, путера̀ и ругове, или: Ут чинйата јаде, у аранѝита гледа, како и: Тај живее да јаде, не јаде да живее. Нашиот човек ја разбира желбата на човекот да касне убаво, да се напие, па советува: Биди срвен, ама не биди лаком, но и: Коа мачка јаде мас, јаде по гас. Потоа: Лаком гас два стапа јаде, и, на крајот: Н'јдѐл, m' з'јдѐл.

Во македонските народни пословици и поговорки свои рефлексии имаат и маните и недостатоците кај луѓето. Во овие искази народниот мудрец е поблаг во исказот и јазикот не е толку остар како кај другите негативни карактерни особини: И либлибѝ'a d’ јаде, ќе се пока́ne. Со една поговорка благо се укажува дека секој човек има по некој недостаток, па, како утеха, ќе рече: И попадиката има маана́, или: Крушка без рачка не може. Ама, понекогаш луѓето се крајно безоблирни и сурови, па ако: Маана́ на чувѐк не мож' d’ му наam, на ќепето ќе му наam (...најдат). Сосема нормално, луѓето со физички мани и недостатоци настојувале колку-толку да ги прикријат, па оттука пословицата: Крии си мааните к'mу зми'а ноојсто (...нозете). Има пословици во кои недостатоците се прикажуваат во позитивна конотација: $\mathrm{Ha}$ лубеницата јам'ко, на жената сакатл'ко (... се слатки).

Има и поговорки и пословици во кои се делат совети: На стар и пијан cмеј ce, а на сака́m - не се смеј. Понекогаш ваквите пословици можат и да нѐ насмеат: Он нема заб д’ убеле, n' ча́чкалица сака. Благо се исмеваат ниските луѓе: $Н$ низок чувѐк ак'ло мо а блиско ду газо. Има и поговорки што се одликуваат со суровост, која се граничи со злоба. За човек со физичка мана некој ќе рече: Тај е од Господ белѐжен. Дури се советува: Уm m’коф подалеку. Сепак, на крајот стои сознанието дека: Чувѐк без маана́ нема. 
Здравјето и болестите, искуството и сознанијата на постарите генерации, карактерните особини на луѓето, верувањето во касметот (среќата), љубовта и омразата во сите нејзини манифестации, маните и недостатоците, односите меѓу мажите и жените во бракот и надвор од него, младоста и староста, надежта, верата, вербата и верувањето, обичаите и традициите, интелигенцијата и снаодливоста наспроти затапеноста и глупавоста, функцијата и силата на парите и богатството, политиката, одделните професии, особено поповите, правдата и неправдата, работливоста и мрзата, радоста и тагата, религијата и црквата, родителите и децата, нивниот однос и воспитувањето, односите меѓу снаата и свекрвата од сите аспекти, среќата и несреќата, судбината, убавината, упорноста како фактор за успех, учењето, храброста и стравот, човечноста и солидарноста и уште многу други содржини што се составен дел на животот и се манифестации на тој ист живот, пулсираат во пословиците и во поговорките.

Затоа една туркменска пословица советува: Имаш ли ум, оди по него; немаш ли го, оди по пословицата.

\section{ЛИТЕРАТУРА}

ВУЈАКЛИЈА, М. (1954). Лексикон страних речи и израза. Београд: Просвета. КИТЕВСКИ, М. (2011). Говорни народни умотворби. Скопје: Камелеон. КОТЕВ, И. (2012). Мудроста на вековите Македонски народни пословици и поговорки од Струмица и Струмичко. Струмица: ЛУБ „Благој Јанков Мучето“.

МАКАРИЈОСКА, Л. (2016). Речник на македонската традиционална култура. Скопје.

САЗДОВ, Т. (1970). Преглед на македонската народна проза. Скопје: Култура.

Ivan Kotev

\section{PHYSICAL AND CHARACTER TRAITS IN MACEDONIAN PROVERBS FROM STRUMITCA}

\section{Summary}

This paper deals with proverbs and proverbial saying as folklore genres which depict life in all its manifestations: love and hate, flaws and shortcomings, relationships between men and women in and out of marriage, youth and old age, hope, faith, belief, customs and traditions, intelligence and ingenuity versus stupidity, the function and power of money and wealth, politics, particular professions, justice and injustice, hard work and lust, joy and sorrow, religion and church, humanity and solidarity, and many more that are integral to life and are manifestations of that same life and pulsate in the proverbs and the sayings used in the paper above.

The cited examples are from my personal field researches in Strumitca in the Republic of Macedonia. 